\title{
ПРАВОВИЙ ДОСВІД ЄВРОПЕЙСЬКОГО СОЮЗУ У СФЕРІ СТИМУЛЮВАННЯ РОЗВИТКУ АЛЬТЕРНАТИВНОЇ ЕНЕРГЕТИКИ
}

Молдованов Д. В.

\begin{abstract}
у статті проаналізовано перспективи створення і діяльності комплексів альтернативної енергетики, які 6 мали можливість повноцінно забезпечити потребу України в енергоресурсах. Досліджувались теоретичні та практичні проблеми, з якими доведеться зіткнутися у разі впровадження відновлювальної енергетики в тому вигляді, у якому передбачено в Національній стратегії України до 2035 року. Крім того, у дослідженні наведені можливі правові шляхи подолання зазначених загроз та поступове впровадження такого виду електроенергетики.
\end{abstract}

Ключові слова: альтернативні джерела енергії, відновлювальна енергетика, вітроелектростанції, сонячні електростанції, «зелений» тариф.

В статье проанализированы перспективы создания и деятельности комплексов альтернативной энергетики, которые бы могли полноченно обеспечить потребность Украины в энергоресурсах. Исследовались теоретические и практические проблемы, с которыми придётся столкнуться при внедрении возобновляемой энергетики в том виде, в котором предусмотрено в Национальной стратегии Украины до 2035 года. Кроме того, в исследовании приведены возможные правовые пути преодоления указанных угроз и постепенное внедрение данного вида электроэнергетики.

Ключевые слова: альтернативные источники энергии, возобновляемая энергетика, ветроэлектростанции, солнечные электростанции, «зелёный» тариф.

The article examines the impact of primary energy sources on the state, highlights both the environmental and general legal aspects. The need to introduce newer renewable energy sources is noted. This is not the first year the neighboring European states have been engaged in this activity, following the example of which Ukraine is trying to introduce this type of energy.

However, as we were exploring this topic, we encountered a number of obstacles to its rapid implementation and legal problems in its operation. So these problems affect both the environmental side of public policy and economic and financial.

To the problems that will bring with them alternative energy sources, we distinguish the following: 1. Large area occupied by renewable energy facilities for energy generation. At the same time, similar power generation capacities with primary sources occupy many times smaller land. 2. It is not possible to install wind farms close to cities, as they generate too much noise when generating energy, which causes discomfort not only for humans but also for animals, thus damaging the ecosystem. 3. The tariff aimed at promoting renewable energy is too large, which negatively affects the overall financial picture. Thus, with the current development of renewable energy, we can speak of the rapid depletion of state budget funds to pay the specified tariff. Summarizing the above, it is necessary to state the negative impact of renewable energy, at the level of development that Ukraine has today, on the state of the country as a whole.

Молдованов Д. В., 2019
Without solving these problems, Ukraine will not be able to make full use of renewable energy and receive the mentioned benefits from its operation. Thus, possible means have been found that Ukraine can implement to overcome them and create optimal conditions for the development of the industry in question. These funds are successfully used in European countries, such countries are rapidly developing the renewable energy sector and according to national strategic plans, consider it possible already in 2050 to completely switch to energy consumption generated from alternative sources. This transition will have a positive impact on the economic, political life of the state and increase the national security level of the country.

Key words: alternative energy sources, renewable energy, wind power, solar power, green tariffs.

Постановка проблеми. У всьому світі динамічно розвиваються програми, за якими для відновлювальних джерел енергії відведена головуюча роль на світовому енергетичному ринку. Україна також заохочує впровадження відновлювальних джерел енергіі. Так, надаються державні дотації, податкові пільги та інша державна підтримка для тих, хто вирішив перейти на альтернативні джерела енергії або розпочати діяльність з продажу електроенергії, генерованої з альтернативних джерел.

Відповідно до Директиви 2009/28/€С до 2020 року частка використання відновлюваних джерел енергії в країнах-членах ЄС має становити 20\% від загального обсягу енергопостачання, що дають змогу зменшити залежність від імпортованого викопного палива та підвищити рівень використання нових енергетичних технологій [1].

Нові альтернативні джерела енергії мають певні переваги над старими викопними, які до того жє вичерпаними та можуть закінчитись у майбутньому. Однак при цьому $\epsilon$ і певні загрози у активному розвитку альтернативної енергетики.

Результати аналізу наукових джерел i публікацій демонструють недостатню розробленість цієї теми. Так, недостатніми $є$ дослідження проблематики альтернативної енергетики, а саме недоліків у системі впровадження зазначеної галузі. Так, серед вітчизняних учених зазначену тематику досліджують Н.А. Вальдман, С.С. Дев'яткіна, Н.І. Дунаєвська, Б.К. Ільєнко, Г.М. Калетнік, С.О. Кудря, Л.Л. Озерова, С.Г. Плачкова, М.С. Труб та інші. Серед іноземних дослідників тематики альтернативної енергетики слід назвати таких науковців, як Ван ден Броек, В. Дорнбург, Е. Смитс, А. Фаідж, Б. Фішер та ін.

Метою цієї статті $\epsilon$ визначення потенційних ризиків, що можуть настати за умови переходу на альтернативні джерела енергії без обмежень їх використання, враховуючи європейський досвід та знаходження засобів протидії таким ризикам.

Виклад основного матеріалу. Виробництво та споживання енергії пов'язане з різними видами життє- 


\section{Економічна безпека держави: теорія і практика}

діяльності людини: з обігрівом житла, приготуванням їі, переміщенням людей та виробництвом певних благ цивілізації. На такому етапі всі джерела енергії можливо поділити на:

1) викопні (вугілля, нафта тощо);

2) ядерні і термоядерні джерела енергії;

3) відновлювальні джерела енергії (енергія вітру, сонця, води тощо).

Так, за даними Державної служби статистики України, у 2018 році було спожито в країні 10011 794,42 тонн палива, з яких - 45354 тис. т вугілля, 31623 793,9 м³ природного газу, 2469 508,1 т нафти. Крім того, 34,3\% всієї енергії України імпортується з інших країн світу [4].

Перероблення такої кількості сировини негативно позначається на загальному стані екології. Так, спалювання викопного твердого та рідкого палива супроводжується виділенням вуглекислого, сірчистого i чадного газів, а також пилу, сажі та інших забруднювальних речовин. Видобуток вугілля відкритим способом, як і торфорозробки, ведуть до руйнування та зміни природних ландшафтів. Розливи нафтопродуктів і нафти під час видобутку і транспортування здатні нанести шкоду біосфері на значних територіях. Також через високу вартість енергоносіїв збільшується кінцева вартість продуктів, під час виготовлення яких потрібна значна кількість енергії, у зв'язку з чим конкурентоздатність вітчизняних виробників знижується, що негативно впливає на обсяги промислового виробництва та загальний рівень життя населення.

Нині Україна йде у напрямі стратегічного розвитку та розширення використання відновлювальних джерел енергії в галузі енергетики. Необхідно зазначити, що саме курс на розвиток відновлювальної енергетики продиктований європейськими віяннями, спрямованими на розвиток цієї галузі.

Однак чи справді курс слідування за європейськими стандартами, вибраний Україною, настільки бездоганний та економічно вигідний?

У науковій праці вважається за доцільне розглядати такі різновиди альтернативних джерел енергії, як вітрові та сонячні електростанції, як основні засоби для генерації відновлювальних видів електроенергії.

Так, вітрова електростанція - група вітрових електричних установок або окрема вітрова електроустановка, устаткування і споруди, розташовані на певній території, які функціонально пов'язані між собою і становлять єдиний комплекс, призначений для виробництва електричної енергії шляхом перетворення кінетичної енергії вітру на електричну енергію [15].

На думку O.I. Соловей, вітроустановки виробляють електричну енергію практично без забруднення довкілля, але при цьому їх негативний вплив пов'язаний із відведенням під будівництво значних площ і зміною ландшафту, загрозою загибелі птахів, металоємністю вітроустановок, що зумовлює забруднення під час виробництва металу [11].

Таким чином, основним економічним недоліком вітроенергетичних станцій (BEC) $є$ використання під будівництво ВЕС значних земельних ресурсів. Під потужні промислові ВЕС необхідна площа з розрахунку від 5 до $15 \mathrm{kм}^{2} /$ МВт залежно від рози вітрів і місцевого рельєфу району. Максимальна потужність, яка може бути отри-

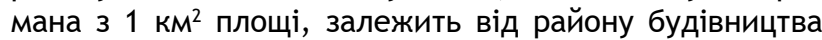
BEC, типу станції і технологічних особливостей кон- струкції; середнє значення отриманої потужності становить приблизно 10 МВт. Для ВЕС потужністю 1000 МВт потрібна площа в 70-200 км². Крім того, вироблення сонячної енергії за допомогою наземних сонячних панелей, які з'єднуються у великі сонячні електростанції, потребують відведення також значних територій. Так, у середньому на 1 МВт баштової сонячної електростанції для слідкуючих геліостатів потрібна площа близько 0,035 км². У цілому площа, необхідна для сонячних електростанцій на 1 МВт потужності, становить по різних країнах світу 0,001-0,008 км² [13].

Однак слід пам'ятати, що земля в Україні $є$ основним національним багатством, яке перебуває під особливою охороною держави [6].

У своїй праці Є.С. Лазеба зазначає, що земля завжди була, $\epsilon$ i буде обмеженим ресурсом, у зв'язку з чим завдання держави - забезпечувати ефективне їі використання. Під ефективністю використання земель необхідно розуміти економічний результат від їх використання [10].

Так, Запорізька атомна станція займає близько 4 кв. км та виробляє близько 6000 МВт [14]. Тобто виходячи із даних, вказаних вище, можна встановити, що для виробітку 6000 МВТ за допомогою відновлювальних джерел енергії потрібно близько 420-1200 кв. км, що $\epsilon$ дуже великою площею для розміщення вітроустановок або сонячних панелей на земельних ділянках.

Крім того, ще один з недоліків таких ВЕС - неприємні звуки, що утворюються під час обертання лопатей ротора. Люди бідкалися, що нерідко під час наближення до електростанції вони починали відчувати дискомфорт, а іноді навіть напади невмотивованого страху. Тварини і птахи мали за краще одразу залишати зони, забудовані ВЕС, а перелітні птахи відхилялися від звичного маршруту і робили гаки в декілька кілометрів, щоб їх облетіти. Особливу екологічну проблему становлять шумові впливи вітроагрегатів потужністю 250 кВт і більше [13].

Крім того, ще одним, та мабуть, основним фінансовим недоліком електростанцій, що виробляють електроенергію з альтернативних джерел енергіі, необхідно вважати вартість електроенергії, за якою держава зобов'язується її купити.

Так, ЗУ «Про альтернативні джерела енергії» встановлено, що «зелений» тариф - спеціальний тариф, за яким закуповується електрична енергія, вироблена на об'єктах електроенергетики, зокрема на введених в експлуатацію чергах будівництва електричних станцій (пускових комплексах), з альтернативних джерел енергії (а з використанням гідроенергії - лише мікро-, міні- та малими гідроелектростанціями) [15].

Отже, відповідно до встановлених тарифів закупівля електричної енергї̈ державою, яку виробляють приватні домогосподарства з енергії сонячного випромінювання об'єктами електроенергетики, величина встановленої потужності яких не перевищує 30 кВт та які введені в експлуатацію з 01 січня 2017 року по 31 грудня 2019 року, становить 550,21 коп/кВт·год (без ПДВ) [16].

Однак роздрібний тариф на електричну енергію, що відпускається для кожного споживача станом на IV квартал 2018 року для I класу напруги, встановлений АТ «ХАРКІВОБЛЕНЕРГО» у 178,079 коп/кВт·год (без ПДВ) та для II класу напруги - 212,776 коп/кВт·год (без ПДВ) [8]. 
За даними, які в своїй статті наводить Б.К. Ільєнко, за останні півтора року в Україні з'являлись щокварталу 400 нових СЕС потужністю близько $8 \mathrm{MBT}$, тобто 2400 CЕС сумарною потужністю 48 МВт.

За даними Інституту відновлюваної енергетики НАН України, у 2017 р. установлена потужність СЕС України становила 740 МВт, вироблено 710 млн кВт·год. електроенергії. Тут доплата за «зелений» тариф становить більш як 3 млрд грн [7].

На сайті Державної служби статистики України міститься інформація про постачання електроенергії з відновлювальних джерел енергії, а саме з сонячної та вітрової енергії. Так, у 2010 році вона становила 4 тис. т н.е.; 2011 рік - 10 тис. т н.е.; 2012 рік - 53 тис. т н.е.; 2013 рік - 104 тис. т н.е.; 2014 рік - 134 тис. т н.е.; 2015 рік - 134 тис. т н.е.; 2016 рік - 124 тис. т н.е.; 2017 рік - 149 тис. т н.е., при цьому дані взяті за 2014-2017 роки без урахування тимчасово окупованої території Автономної Республіки Крим і м. Севастополя та частини тимчасово окупованих територій у Донецькій та Луганській областях [5].

Таким чином, спостерігається велике зростання електроенергії, видобутої з відновлювальних джерел енергії. Крім того, державні видатки, які спрямовані на розвиток сектору альтернативної енергетики, щороку збільшуються, що негативно може відбитися на Державному бюджеті країни.

Вирішенням проблеми з державними видатками на оплату «зеленої» енергії, що все збільшуються, може стати зменшення ставки «зеленого» тарифу до розмірів середнього тарифу, який розрахований для споживачів II класу напруги без ПдВ. Таким чином, держава зможе підтримати енергетичні кооперативи та приватні домогосподарства, генеруючі установки яких виробляють електричну енергію 3 альтернативних джерел енергії та для яких встановлено «зелений» тариф, адже вони здебільшого належать до побутових споживачів, для яких різниця між споживанням ними електричної енергії за тарифом 1,68 грн з ПДВ та продажу 2,1 грн (середнього тарифу, який розрахований для споживачів ІІ класу напруги без ПДВ) буде приносити добрі дивіденди.

Вирішенням проблеми встановлення вітроелектростанцій може слугувати їх встановлення на території, не зайнятої людьми. Так, уряд Великобританії затвердив план, відповідно до якого до 2030 року морські вітроелектростанції мають виробляти третину електроенергії в країні. Уряд Великобританії планує додатково стимулювати бізнес, затвердивши видатки на ці цілі близько 250 мільйонів фунтів стерлінгів (близько 329 мільйонів доларів) [3].

Станом на кінець 2013 року в світі експлуатувалося більше 60 ВЕС, встановлених у морі, загальною потужністю близько 6 ГВт, в основному стаціонарних (2 плавучі в Норвегії та Португалії) і на внутрішніх водоймах (3 - в Німеччині, Нідерландах і Швеції). Більше половини наявної потужності припадає на Великобританію. Крім того, в світі розвиваються технології, які дають змогу ставити ВЕС як на мілководді, так і в місцях, де станція не буде встановлюватись на дні водойми (тобто на глибині), а буде діяти за принципом поплавку [2, с. 211-215].

Крім того, необхідно зазначити, що відповідно до Конвенції ООН з морського права, яка ратифікована ЗУ № 728-XIV від 03.06.1999 № 31, суверенітет прибереж- ної держави поширюється за межі її сухопутної території і внутрішніх вод, а в разі держави-архіпелагу - іï архіпелажних вод, на що примикає морський пояс, званий територіальним морем. Зазначений суверенітет поширюється на повітряний простір над територіальним морем, так само як на його дно і надра. Ширина територіального моря встановлюється та не може перевищувати дванадцяти морських миль, які відміряються від вихідних ліній, визначених відповідно до цієї Конвенції [9].

Глибина територіальних вод України на Азовському морі становить близько 2-4 метрів [12, с. 390], що відмінно підходить для встановлення вітроелектростанцій на морському дні.

Користуючись прикладом уряду Великобританії пропонується також стимулювати бізнес у цьому напрямі шляхом надання відповідних дотацій на будівництво морських вітрових електростанцій, підвищеного «зеленого» тарифу порівняно з наземними електростанціями відновлювальної енергетики, за яким буде закупатись згенерована електроенергія, та податкових пільг для зазначеного бізнесу.

Висновки. У статті наголошується про необхідність подальшого реформування системи електроенергетики в галузі альтернативної енергетики. Зазначається, що держава щороку втрачає великі кошти з державного бюджету на стимулювання споживачів та виробників електроенергії з альтернативних джерел енергії шляхом купівлі електроенергії за «зеленим» тарифом, що значно вищий за показники в інших країнах та економічно не дуже вигідний для самої України.

Крім того, ставиться питання про скасування або зменшення «зеленого» тарифу та впровадження нових стимулюючих заходів для виробників електроенергії з альтернативних джерел.

Також задля економії земельних ресурсів України пропонується займатись розробкою та впровадженням вітроелектростанцій на морі, а саме на смузі в Азовському морі, яка належить Україні на праві територіальних вод.

\section{Література}

1. Directive 2009/28/EC of the European Parlment and of the Council of 23 April 2009 on the promotion of the use of energy from renewable sources. URL: https: / / eur-lex.europa. eu/legal-content/EN/ALL/?uri=CELEX\%3A32009L0028.

2. Вальдман Н.А. Морские ветровые електростанции / Н.А. Вальдман, М.С. Труб, Л.Л. Озерова. Санкт-Петербург. Крыловский государственный научный центр, 2015. № 86 (370). С. 209-220.

3. До 2030 року третину електроенергії Британії вироблятимуть вітряки, розташовані у морі. Новинний портал Finance.ua. 2019. URL: https://news.finance.ua/ru/news//445292/do-2030-goda-tret-elektroenergii-britanii-budutvyrabatyvat-vetryaki-raspolozhennye-v-more.

4. Енергетичний баланс України (продуктовий). Державна служба статистики України. URL: http://www.ukrstat.gov.ua/.

5. Енергоємність за 2007-2017 роки. Державна служба статистики України. URL: http: / / www.ukrstat.gov.ua/.

6. Земельний кодекс України : від 25 жовтня 2008 р. № 2768-III. Відомості Верховної Ради України. 2002. № 3-4.

7. Ільєнко Б. Переваги застосування відновлюваних джерел енергії не такі однозначні. Інтернет-видання ZN.UA. 2018. URL: https://www.dt.ua/energy_market/ navischo-y-komu-mi-oplachuyemo-zeleniy-tarif-287103_. html. 


\section{Економічна безпека держави: теорія і практика}

8. Інформація щодо роздрібних тарифів на електричну енергію, що відпускається для кожного класу споживачів, крім населення, на території України на IV квартал 2018 року. / HKPЕКП. URL: http:/ / www.nerc.gov.ua/?id=34869.

9. Конвенція Організації Об'єднаних Націй з морського права від 03.06.1982 (ратифікована Законом України № 728-XIV від 03.06.1999). Відомості Верховної Ради України (ВВР), 1999, № 31, ст. 254.

10. Лазеба Є.С. Підвищення ефективності використання земель сільськогосподарського призначення в Україні. Ефективна економіка. URL: http://www.economy.nayka. com.ua/?op=1\&z=3062.

11. Ландау Ю.О. Електроенергетика та охорона навколишнього середовища. Функціонування енергетики в сучасному світі. Частина 1. Розділ 3. Перспективи розвитку відновлювальної нетрадиційної енергетики / С.О. Кудря, Ю.О. Ландау, О.І. Соловей. URL: http://energetika.in.ua/ua/books/book-5/part1/section-3].

12. Масляк П.О. Проблемы охраны природных систем Чёрного и Азовского морей и водных ресурсов / П.О. Масляк, П.Г. Шищенко. Географія України : підручник для 8-9 класів середньої школи. Київ : Зодіак-ЕКО, 2000. 434 c.
13. Науково-пізнавальне видання «Енергетика: історія, сучасність і майбутнє». Книга 5. Електроенергетика та охорона навколишнього середовища. Функціонування енергетики в сучасному світі. Енергетика. Історія, сучасність і майбутнє. URL: http://energetika.in.ua/ua/books/ book-5.

14. Пам'ятні дати та події. Запорізька AEC. URL: https://www.npp.zp.ua/uk.

15. Про альтернативні джерела енергії : Закон України від 20 лютого 2003 року № 555-IV. Відомості Верховної Ради України. 2003. № 24. Ст. 155.

16. Про встановлення «зелених» тарифів на електричну енергію для приватних домогосподарств : Постанова Національної комісії, що здійснює державне регулювання у сферах енергетики та комунальних послуг від 23 березня 2019 року № 447 / НКРЕКП: офіційний вебсайт. URL: http: / / www.nerc.gov.ua/?id=39687.

Молдованов Д. В., аспірант Харківського національного університету внутрішніх справ 